Perspective

\title{
Current Legal Framework on Shallow Geothermal Energy Use in Spain
}

\author{
Alejandro García Gil *, Miguel Mejías Moreno \\ Geological Survey of Spain (IGME), C/Ríos Rosas 23, 28003 Madrid, Spain \\ * Correspondence: Alejandro García Gil, Email: a.garcia@igme.es; \\ Tel.: +34-976-555-153.
}

\begin{abstract}
A steady increase in the use of shallow geothermal energy can be observed worldwide in past years. In order to highlight the necessity of a specific detailed legal framework for shallow geothermal energy systems, an overview of the current legal framework in Spain is carried out in this paper. Findings show complex legislation at the national level and a high diversity among regional governments in Spain. There is no legally binding definition of shallow geothermal energy resources and the deep geothermal approach of the past is embedded in the legislation inherited from 40 years ago. In consequence, the lack of specific legislation makes the licensing process of systems an effective barrier for the further development of the market, thus indicating the need for a common approach. This work highlights the need for a shallow geothermal energy management framework structure and a governance model based on an adaptive management approach, including both management planning and implementation as well as control cycles.
\end{abstract}

KEYWORDS: shallow geothermal energy; regulations; legal framework; smart cities; heating and cooling

\section{G Open Access}

Received: 07 October 2019

Accepted: 18 December 2019

Published: 19 December 2019

Copyright (c) 2019 by the author(s). Licensee Hapres, London, United Kingdom. This is an open access article distributed under the terms and conditions of Creative Commons Attribution 4.0 International License.

\section{ABBREVIATIONS}

GSHP, ground source heat pump; GWHPs, groundwater heat pump systems; BHE, borehole heat exchangers

\section{INTRODUCTION}

The use of shallow underground areas up to $400 \mathrm{~m}$ below the ground surface as a heat source/sink reservoir has been revealed as a promising measure for saving energy. A combination of borehole heat exchangers (BHE) and heat pumps, known as geothermal heat pump systems, is nowadays used in residential houses and building blocks to extract/dissipate heat into the subsurface for indoor air conditioning and heating. The energy transferred using these systems is referred to as shallow geothermal energy. Heat exchangers can be buried underground and can circulate a water antifreeze solution through the inside of the pipe network, transferring heat from the ground to the heat pump or, 
alternatively, groundwater can be pumped from underground and circulated through a liquid-liquid heat exchanger situated on the surface. The first approach results in shallow geothermal energy systems known as closed-loop systems (or ground source heat pump, GSHP) and the second in open loop systems (or groundwater heat pump systems, GWHPs). When seasonal offsets between thermal energy demand and supply are considered, Underground Thermal Energy Storage (UTES) technology has been of great success using open-loop systems (referred to as Aquifer Thermal Energy Storage (ATES)) or closed-loop systems (referred to as Borehole Thermal Energy Storage (BTES)) [1].

The use of shallow geothermal energy systems for heating or cooling purposes is experiencing explosive growth worldwide. Between 2010 and 2015, the world's total installed capacity of geothermal heat pumps increased at an annual rate of $13.2 \%$ up to 50,258 MWt total capacity, with an annual energy use of 326,848 TJ/year [2]. The equivalent number of installed $12 \mathrm{~kW}$ units is approximately 4.19 million, which represents a $52 \%$ increase over the number of installed units in 2010 [2]. This could be explained by different factors. For example, it could be explained by the partial substitution for fossil fuel energy by increasing the overall efficiency of thermal power plants [3] as one of many promising measures to reduce fossil fuel use, thus resulting in energy safety and price independence. The energy efficiency of geothermal heat pumps is about $50 \%$ to $70 \%$ higher than that of conventional heating systems, and $20 \%$ to $40 \%$ better than that of available air conditioners [4]. Recent developments are also motivated by global warming. The climate change mitigation possibilities of these systems have been proven. For example, in 2008, the use of around 879,000 shallow geothermal energy heat pump systems in nineteen European countries saved $3.7 \times 10^{6} \mathrm{t} \mathrm{CO}_{2}$ (eq.) in comparison to conventional heating practices [5]. The fact that this particular application of geothermal energy can be installed anywhere with no specific geological requirements (in the case of GSHP systems) has made people aware of the technical, environmental, and economic advantages of geothermal heat pumps [6].

The legal framework for the regulation of shallow geothermal energy systems in countries around the world is still under development. The literature shows the diversity of approaches to the use of shallow geothermal energy throughout the world [7-9], including that it is regulated more heavily in European countries due to the fact that shallow geothermal energy is commonly used there [10]. In other countries, either deep geothermal energy is more commonly used or the standards are weak and partially vague. Some common approaches consider establishing a minimum distance of between 2.5 (Austria) and $10 \mathrm{~m}$ (Finland and Sweden) from the closed geothermal systems to the property lines [11]. In open geothermal systems, threshold values between 15 and $25{ }^{\circ} \mathrm{C}$ for cooling and between 2 and $5{ }^{\circ} \mathrm{C}$ for heating the groundwater have been proposed $[12,13]$. There is no common approach 
defining threshold values but a high variability of values that also seem to be empirically defined rather than scientifically evaluated $[7,13]$. In Spain, there is a lack of a clear legal framework on shallow geothermal energy systems because no statutes, regulations or ordinances exist [7,9]. Previous studies suggest [8] that the general regulations (not specific to shallow geothermal energy) are limited to specifications in technical codes and regulations to indicate that these systems could be considered as possible solutions for the reduction of the energy demand in buildings, which will in turn save energy. Finally, a review of the legal framework for shallow geothermal energy in selected European countries concluded that there is no common overall specific permitting procedures and regulations for shallow geothermal energy systems in Spain [13]. The objective of this paper is to provide an outlook of the limited legal framework in Spain in relation to shallow geothermal energy systems in order to promote further development of a national market. In the end, this will contribute to the increase of renewable energy use that society is seeking to achieve sustainable energy production in a global warming framework.

\section{SHALLOW GEOTHERMAL ENERGY DEFINITION}

According to the Spanish National Geothermal Platform [14], shallow geothermal energy is defined as the energy stored as heat in the first $250 \mathrm{~m}$ below the surface. The associated geothermal energy resources are considered to rely on the temperature of the solid phase of the geological media and the groundwater within, showing temperatures below $30^{\circ} \mathrm{C}$, and usually around the mean annual surface temperature of the site considered. This definition is presented by the Spanish National Geothermal Platform, a national level cluster of stakeholders involved in this sector, including industry, scientific researchers and governmental authorities. No legally binding definition is available in Spain.

\section{TECHNICAL GUIDELINES FOR GOOD PRACTICES}

A first guide titled "Materials Guide for the design, implementation and monitoring of closed geothermal systems" [15] describes the procedures to design, plan, and install closed loop vertical geothermal heat exchangers. The purpose of this standard is to define and promote the appropriate installation of geothermal interconnection systems for vertical closed-circuit heating, cooling and sanitary hot water production, thus guaranteeing the energy efficiency of the installations as a whole. It also takes into account the technical requirements of the collection and its integration with the heating system, refrigeration system and generation of sanitary water and/or water for industrial uses.

A second guide titled "Technical guide for the design of geothermal heat pump systems" [16] intends to set the minimum technical conditions required for closed loop geothermal systems used for space 
heating/cooling and sanitary hot water production, specifying the design, installation and maintenance requirements.

\section{REGULATIONS ON USE OF SHALLOW GEOTHERMAL ENERGY}

Spain specifically regulates neither the installation nor the operation of the systems of shallow geothermal energy resources exploitation. Shallow geothermal energy exploitation falls within a complex legal framework (Figure 1) where two main dimensions of complexity can be found:

(1) The multidisciplinary nature of the activities involved (geological energy resources, heating/cooling facilities and environmental concerns), which are affected by four previously existing Acts that do not consider this technology, and

(2) In Spain, the legal competences of mining, environmental impact assessment and water have been transferred from the national level to a regional level.

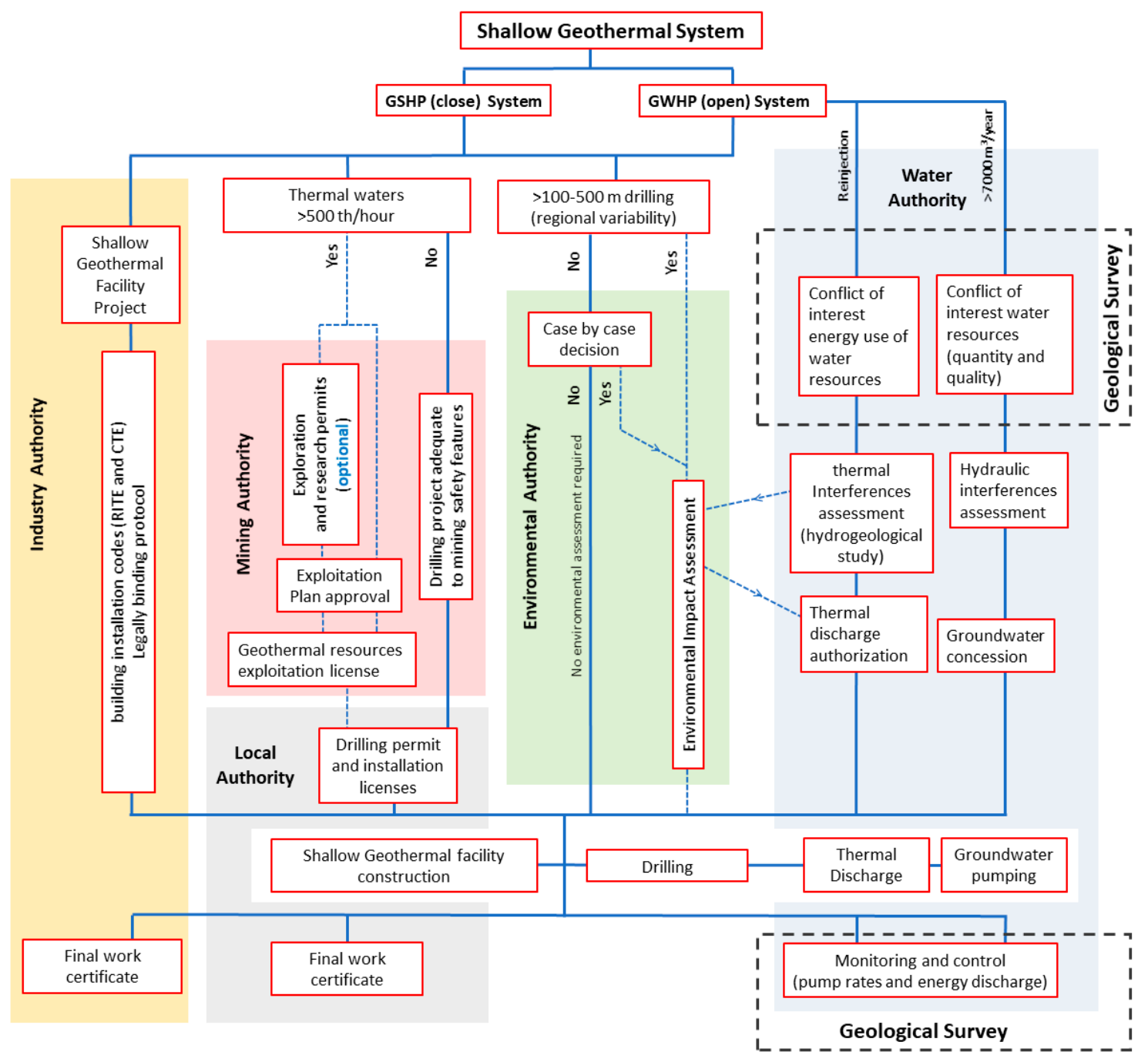

Figure 1. Flowchart showing procedures and regulations for assessing applications and granting licenses on shallow geothermal energy. 
At the national level (Table 1), the Mines Act (L22/1973) and the associated Regulations (RD2857/1978, RD863/1985) define the legal concepts of geothermal energy resources and thermal waters. Deep and shallow geothermal energy resources are not differentiated, but a potential future definition is considered, thus requiring a proposal of the Energy and Mining Ministry with the endorsement of a previous report elaborated by the Geological Survey of Spain. In general, electricity production and direct use of geothermal energy resources are subject to obtaining exploration and investigation permits and a license approval. The license is granted for 30 years. However, the Mining Act does not apply to geothermal installations where the resources extracted are used for the owner's own interest and mining methods are not used for exploitation. If thermal waters (groundwater with a temperature value of $4{ }^{\circ} \mathrm{C}$ above the mean annual surface temperature of the site) are used for space heating/cooling and the exploitation exceeds $500 \mathrm{th} / \mathrm{h}(581 \mathrm{kWh})$, the installation will then require the aforementioned permits and licensing. In conclusion, ordinary shallow geothermal energy installations are not affected by this law, as it is only applied when thermal waters are used, and thermal waters use would be an exception. At the regional level (Table 1), regional authorities are allowed to complement the National Basic Act. Nevertheless, only the region of Galicia has its own Mining Act and it does not distinguish further among geothermal energy resources.

Table 1. Documents conforming the legal framework for the use of shallow geothermal energy.

\begin{tabular}{|c|c|c|}
\hline $\begin{array}{l}\text { Regulation } \\
\text { levels }\end{array}$ & Legal documents & $\begin{array}{l}\text { Character of } \\
\text { documents }\end{array}$ \\
\hline National & Mines Act (L22/1973, L54/1980) [17,18] & Obligatory \\
\hline National & Regulations under Mines Act (RD2857/1978, RD863/1985) [19] & Obligatory \\
\hline National & $\begin{array}{l}\text { Guide for the design, implementation and monitoring of close geothermal systems (UNE100715-1) } \\
\text { [15] }\end{array}$ & Recommended \\
\hline National & Technical guide for the design of geothermal heat pump systems (ATECYR-IDAE) [16] & Recommended \\
\hline National & $\begin{array}{l}\text { Technical Building Code (CTE) and Regulation for Thermal Installations in Buildings (RITE, } \\
\text { RD238/2013) [20] }\end{array}$ & Obligatory \\
\hline National & Environmental Impact Assessment Act (RDL1/2008, L6/2010, L21/2013) [21-23] & Obligatory \\
\hline National & Regulations under the Environmental Impact Assessment Act (RD1131/1988) [24] & Obligatory \\
\hline National & Water Act (RDL1/2001) [25] & Obligatory \\
\hline National & Regulations under the Water Act (RD849/1986, RD 638/2016) $[26,27]$ & Obligatory \\
\hline Regional & $\begin{array}{l}\text { Environmental Protection Acts for the Andalucía, Aragón, Cantabria, and Illes Balears regions } \\
\text { (L7/2007, L11/2014, L17/2006, L16/2015, Ley 12/2016) [28-32] }\end{array}$ & Obligatory \\
\hline Regional & Mines Act for the Galicia region (L3/2008) [33] & Obligatory \\
\hline Regional & $\begin{array}{l}\text { River basin management plans of the Duero, Ebro, Miño-Sil, and Tajo catchments and the } \\
\text { Cantabria Domain (RD1/2016) [34] }\end{array}$ & Obligatory \\
\hline Local & $\begin{array}{l}\text { Municipal Ordinance regulating drilling permits (Ordenanza Municipal de Medios de Intervención } \\
\text { en la Actividad Urbanística, 2011) [35] }\end{array}$ & Obligatory \\
\hline Local & Technical guide for the design of geothermal heat pump systems (ATECYR-IDAE) [16] & Obligatory \\
\hline
\end{tabular}


At a national level, the Environmental Impact Assessment Act (RDL1/2008) and the associated Regulations (L6/2010, L9/2006) consider heat as a contaminant and suggest that environmental impact assessment and monitoring should be potentially required. However, there are no unified criteria to determine which geothermal systems would be affected by this Act. At a regional scale, only the regions of Andalucía (Figure 2A1), Aragón (Figure 2A2), Cantabria (Figure 2A3) and Illes Balears (Figure 2A4) have delimited depths where environmental impact assessment is mandatory (500, 500, 100 and $400 \mathrm{~m}$, respectively). This indicates that environment impact assessment is not generally mandatory for shallow geothermal energy systems.

The national Water Act (RDL1/2001) regulates the thermal discharges of GWHP systems, forcing the users to obtain a license for the volume of groundwater extracted and reinjected into the aquifer (water concession), as well as a discharge authorization. The thermal discharge authorization requires a hydrogeological study and an environmental impact assessment, including potential impacts to the environment and potential thermal impacts to other users of shallow geothermal energy systems. Closed systems are generally excluded from these assessments. At a regional level, the Hydrographic Confederations (competent authorities) of the Duero (Figure 2B1), Ebro (Figure 2B2), Miño-Sil (Figure 2B3), and Tajo (Figure 2B4) catchments and the Cantabrica Domain (Figure 2B5) have introduced different considerations in their respective River Basin Management Plans (RD1/2016) to maintain good thermal quality of their groundwater bodies, including maximum relative temperature change values between captation and injection wells (6 to $\left.8^{\circ} \mathrm{C}\right)$ and maximum temperature thresholds $\left(30^{\circ} \mathrm{C}\right)$.

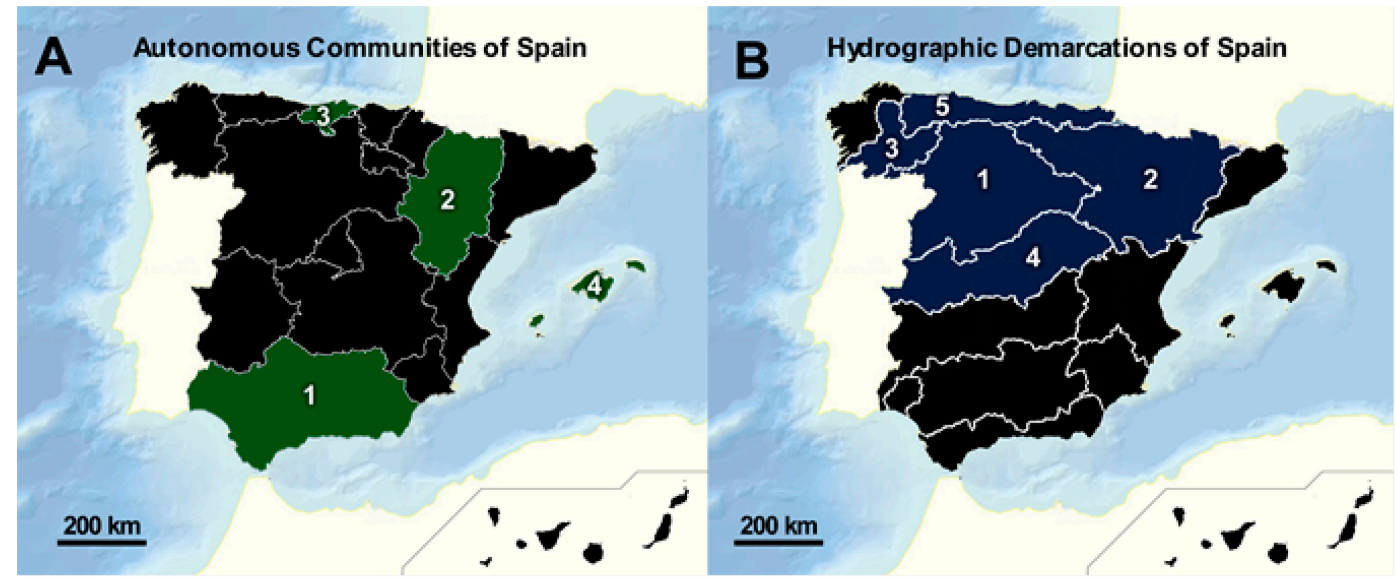

Figure 2. (A) Spanish Autonomous Communities. The Autonomous Communities of Andalucía (1), Aragón (2), Cantabria (3) and Illes Balears (4), where environmental impact assessment is mandatory for given drilling depths are highlighted in green. (B) Spanish Hydrographic Demarcations. Hydrographic Demarcations of the Duero (1), Ebro (2), Miño-Sil (3), and Tajo (4) catchments and the Cantabrica Domain (5), where requirements related to the maintenance of good thermal quality of groundwater bodies have been adopted, are highlighted in blue. Base maps were obtained from the Spanish Ministry for the Ecological Transition. 
Finally, the efficiency, safety, control and responsibilities of the shallow geothermal energy facilities (from an engineering perspective) are regulated by the Technical Building Code (CTE) and the Regulation for Thermal Installations in Buildings (RITE, RD238/2013) promulgated by the Ministry of Industry. These documents describe the requirements to design the installation project, the execution of the works and the legalization procedure.

\section{APPLICATION FOR SHALLOW GEOTHERMAL ENERGY SYSTEM INSTALLATIONS AND LICENSING}

There is no specific form or protocol in order to obtain an exploitation license for shallow geothermal energy systems in Spain. The permits required to operate a shallow geothermal energy system are indirectly related to the infrastructure required for its operation and interaction with the environment. For example, any thermal installation for space heating/cooling in Spain is considered to be part of the building process and is regulated by the Technical Building Code (CTE) and the Regulation for Thermal Installations in Buildings (RITE) document. Both legal instruments are approved by the Industry Ministry of Spain and provide the requirements necessary to fulfil the acceptable conditions for the thermal installation. In an initial phase, the RITE regulation document requires the preparation of a supporting document where the thermal system chosen is justified according to the building demand and objectives. In a second phase, the thermal system is installed and the potential modifications from the initial design are reported to the industrial authorities. After that, the authorities revise the documentation and perform a site inspection to ensure RITE requirements are fulfilled. If the requirements are met, then the authorities issue a favorable report, thus legalizing the thermal system.

Shallow geothermal energy resources are not legally differentiated from deep geothermal energy resources in Spain. Therefore, those resources are protected and regulated by the mining authority. The National Mining Act only requires a geothermal energy resources exploitation license for non-domestic systems (large systems), and exclusively when mining methods are used during the exploitation phase of the resource, and thus does not apply to shallow geothermal energy systems where drilling methods are only applied for the exploitation infrastructure (BHE or deep wells) before exploiting the resource itself. Nevertheless, the mining authority requires a drilling project that complies mining safety features required for shallow geothermal energy systems. Once approved, permits and licenses from the relevant local authority are required in most regions. If thermal waters are exploited by shallow geothermal energy systems, then the approval of a full exploitation plan, which is complex and very time-consuming to prepare, is required. 
The environmental authority will not require a mandatory Environmental Impact Assessment (EIA) when drilling is shallower than 100 to $500 \mathrm{~m}$, depending on the region of Spain. An EIA is mandatory for deep geothermal exploitation or when stimulated geothermal techniques are applied. In general terms, the Environmental authority will make a case-by-case decision. Depending on this decision, no EIA will be required, but only a simplified (3 months extendable up to 6 months) or ordinary EIA will be requested (19 months extendable up to 21 months).

In addition to all these permits and licenses, if a GWHP system is considered, obtaining different additional authorizations from the water authorities is required. When pumped groundwater exceeds $7000 \mathrm{~m}^{3} /$ year, a water concession is required. If heated/cooled groundwater is reinjected into the aquifer, then a thermal discharge authorization is required, together with a hydrogeological study assessing the thermal impact caused to other GWHP systems' users as well as the potential geochemical impacts. Different regional water authorities have their own sustainability threshold values for characteristics such as maximum injection temperatures and relative extraction/injection temperature changes. The Geological Survey of Spain has a role in the monitoring of environmental impacts and in controlling system exploitation regimes, in the identification of thermal interferences between systems and in the proposal of sustainability thresholds [36].

\section{SPECIAL REQUIREMENTS FOR INSTALLATION AND OPERATION OF SHALLOW GEOTHERMAL ENERGY SYSTEMS}

In Spain, an Environmental Impact Assessment is only required by the Environmental Authority when drilling exceeds $500 \mathrm{~m}$ in depth. The National legal framework does not set a depth threshold value and this responsibility is passed to the regional authorities. In pioneer areas like the city of Zaragoza, GWHP systems are allowed to inject pumped groundwater with temperatures up to $30^{\circ} \mathrm{C}$ calculated as an equivalent daily value integrating the total energy dissipated during the daily activity. An $8{ }^{\circ} \mathrm{C}$ relative temperature change is allowed between the extraction and injection wells of a GWHP system. In addition, installations of more than $200 \mathrm{~kW}$ are continuously monitored, and 15-minutal datasets of injection/captation temperatures and flow rates must be reported to the water authority.

The decommissioning of operational boreholes is only regulated by the Water Act when they affect the Hydraulic Public Domain (RD849/1986) but there is not a specific protocol [37]. The Mining Act also enforces the re-establishment of natural conditions once the exploitation has finished. No specific regulations for shallow geothermal energy systems are considered by law.

There is no general legal requirement for reporting the operational regime of a shallow geothermal energy system to the authorities. In 
case-to-case situations, the authorities have the right to demand such reports when preventing overexploitation or environmental damage is a consideration. In the pilot area of Zaragoza City, the local water authority requires users to report 15-min measurements on captation and injection temperatures as well as the pumping rates for GWHP systems.

Further legislative development in Spain seems to require a national scale framework establishing the need for defining specific minimum requirements for the different regional and local authorities. First, a shallow geothermal energy management framework structure and a governance model would be desirable. They should be based on an adaptive management approach that includes management planning and both implementation and control cycles. Among other things, it would be necessary to demand the establishment of an inventory of shallow geothermal energy systems, with the objective of defining thermal protection perimeters [38,39] around geothermal installations and to implement them in GIS-Based Software Platforms. This would allow an installed power threshold value (e.g., $50 \mathrm{~kW}$ ) to be defined as a criterion to perform a simplified or regular licensing procedure that would assess if a complete environmental impact analysis is required. The $50 \mathrm{~kW}$ threshold value is based on the typical shifting capacity value from residential/domestic systems to commercial and public sector systems [40].

A special characteristic of Spain is its climate. According to the Spanish State Meteorological Agency, the average air annual temperature in Spain is $15.1{ }^{\circ} \mathrm{C}$ (1981-2010) and increasing [41], which is relatively higher than that of the rest of the northern European countries. The implication of this characteristic is basically that the cooling demand is higher than the heating demand, thus making it necessary to impose a relatively high injecting temperature limit of $30^{\circ} \mathrm{C}$ or higher, considering the equivalent daily injection temperature obtained from the integration of the energy transferred to the subsurface for each day of operation and not from punctual measurements [42]. Threshold values for urban areas where shallow geothermal energy systems are concentrated should be differentiated from non-urban ones, i.e., areas where thermal interference is negligible due to the lack of installations or the several kilometer distances between systems. In addition, environmental constraints on maximum injection temperatures in Mediterranean areas are yet to be investigated [43-46].

\section{CONCLUSIONS}

In summary, the Spanish legal framework does not directly differentiate shallow geothermal energy resources from general geothermal energy resources, but does so indirectly by delimitating operation depths $(100-500 \mathrm{~m})$ at a regional level, where regulations enforce licensing and environmental impact assessment protocols for deep geothermal systems. These regulations thus indirectly define 
shallow geothermal energy resources that are not regulated in general. Requirements similar to those that apply to deep geothermal systems are only applied to open systems if shallow geothermal energy systems are using shallow groundwater, however, leaving closed loop systems without any kind of regulation in most regions of Spain.

There is sound evidence that a specific legal framework should be elaborated. Shallow geothermal energy should be defined in the Mining Act, including a depth threshold of $400 \mathrm{~m}$ for domestic heating and cooling. Drilling technology up to $400 \mathrm{~m}$ does not pose a risk to the environment. Systems with an installed power below $50 \mathrm{~kW}$ should be offered a simplified procedure including essential information. From 50 to $200 \mathrm{~kW}$, an extended project report would be advisable that should include a hydrogeological report assessing thermal interferences and the possible interaction with contaminated groundwaters. Systems exceeding $200 \mathrm{~kW}$ and those designed for district heating in urban environments should be required to perform an exhaustive EIA and to be monitored and to be kept under surveillance by the environmental authorities or water authorities when groundwater is involved in the exploiting process. Coordination efforts between authorities should be made to organize the process in a way that allows the users to perceive the license process as a single application.

Any effort for the economical promotion of shallow geothermal energy exploitation as an environmentally friendly and economically efficient technology is futile if a reliable, simple and fast legal procedure, specifically developed for shallow geothermal energy systems, is not offered to potential users.

\section{ACKNOWLEDGMENTS}

This work was undertaken within the project MUSE-Managing Urban Shallow Geothermal Energy. This project has received funding from the European Union's Horizon 2020 research and innovation programme under grant agreement No 731166. This research was also partially supported by the research group Geología Aplicada E01_17R recognized by the Spanish Autonomous Community of Aragon.

\section{REFERENCES}

1. Fleuchaus P, Godschalk B, Stober I, Blum P. Worldwide application of aquifer thermal energy storage-A review. Renew Sustain Energy Rev. 2018;94:861-76.

2. Lund JW, Boyd TL. Direct Utilization of Geothermal Energy 2015 Worldwide Review. In: Proceedings World Geothermal Congress 2015; 2015 Apr 19-25; Melbourne, Australia. Bonn (Germany): International Geothermal Association; 2015.

3. Stauffer F, Bayer P, Blum P, Giraldo NM, Kinzelbach W. Thermal Use of Shallow Groundwater. 1st ed. Boca Raton (US): CRC Press; 2013. 
4. Letcher TM, editor. Future Energy: Improved, Sustainable and Clean Options for our Planet. 2nd ed. Amsterdam (The Netherlands): Elsevier Science; 2013.

5. Bayer P, Saner D, Bolay S, Rybach L, Blum P. Greenhouse gas emission savings of ground source heat pump systems in Europe: A review. Renew Sustain Energy Rev. 2012;16(2):1256-67.

6. Abesser C. Open-loop ground source heat pumps and the groundwater systems: A literature review of current applications, regulations and problems. Nottingham (UK): British Geological Survey; 2010.

7. Haehnlein S, Bayer P, Blum P. International legal status of the use of shallow geothermal energy. Renew Sustain Energy Rev. 2010;14(9):2611-25.

8. Jaudin F. REGEOCITIES D2.2: General Report of the current situation of the regulative framework for the SGE systems. Brussels (Belgium): European Geothermal Energy Council; 2013.

9. Somogyi V, Sebestyén V, Nagy G. Scientific achievements and regulation of shallow geothermal systems in six European countries-A review. Renew Sustain Energy Rev. 2017;68:934-52.

10. Francesco T, Annamaria P, Martina B, Dario T, Dušan R, Simona P, et al. How to boost shallow geothermal energy exploitation in the adriatic area: The LEGEND project experience. Energy Policy. 2016;92:190-204.

11. Hähnlein S, Molina-Giraldo N, Blum P, Bayer P, Grathwohl P. Cold plumes in groundwater for ground source heat pump systems [Ausbreitung von Kältefahnen im Grundwasser bei Erdwärmesonden]. Grundwasser. 2010;15(2):123-33. German.

12. Hähnlein S, Bayer P, Ferguson G, Blum P. Sustainability and policy for the thermal use of shallow geothermal energy. Energy Policy. 2013;59:914-25.

13. Tsagarakis KP, Efthymiou L, Michopoulos A, Mavragani A, Anđelković AS, Antolini F, et al. A review of the legal framework in shallow geothermal energy in selected European countries: Need for guidelines. Renew Energy. 2020;147(2):2556-71.

14. GEOPLAT. Vision for 2030. Madrid (Spain): Spanish Ministry of Economy and Compettiveness; 2010.

15. UNE100715-1:2014. Guide for the design, implementation and monitoring of a geothermal system. Part 1: Vertical closed circuit systems. Madrid (Spain): UNE; 2014.

16. ATECYR. Guía técnica Diseño de sistemas de intercambio geotérmico de circuito cerrado. Madrid (Spain): Instituto para la Diversificación y Ahorro de la Energía (IDAE); 2012. Spanish.

17. L22/1973, Ley 22/1973, de 21 de julio, de Minas. Madrid (Spain): Jefatura del Estado, Official State Bulletin; 1973. Spanish.

18. L54/1980, Ley 54/1980, de 5 de noviembre, de modificación de la Ley de Minas, con especial atención a los recursos minerales energéticos. Madrid (Spain): Jefatura del Estado, Official State Bulletin; 1980. Spanish.

19. RD2857/1978, Real Decreto 2857/1978, de 25 de agosto, por el que se aprueba el Reglamento General para el Régimen de la Minería. Madrid (Spain): Ministerio de Industria y Energía, Official State Bulletin; 1978. Spanish. 
20. RD238/2013, Real Decreto 238/2013, de 5 de abril, por el que se modifican determinados artículos e instrucciones técnicas del Reglamento de Instalaciones Térmicas en los Edificios, aprobado por Real Decreto 1027/2007, de 20 de julio. Madrid (Spain): Ministerio de la Presidencia, Official State Bulletin; 2013. Spanish.

21. RDL1/2008, Real Decreto Legislativo 1/2008, de 11 de enero, por el que se aprueba el texto refundido de la Ley de Evaluación de Impacto Ambiental de proyectos. Madrid (Spain): Ministerio de Medio Ambiente; 2008. BOE-A-2008-1405. Spanish.

22. L6/2010, Ley 6/2010, de 11 de junio, reguladora de la participación de las entidades locales en los tributos de la Comunidad Autónoma de Andalucía. Madrid (Spain): Órgano Presidencia De La Junta De Andalucia, Official State Bulletin; 2010. BOE-A-2010-11492. Spanish.

23. L21/2013, Ley 21/2013, de 9 de diciembre, de evaluación ambiental. Madrid (Spain): Jefatura del Estado, Official State Bulletin; 2013. Spanish.

24. RD1131/1988, Real Decreto 1131/1988, de 30 de septiembre, por el que se aprueba el Reglamento para la ejecución del Real Decreto Legislativo 1302/1986, de 28 de junio, de Evaluación de Impacto Ambiental. Madrid (Spain): Ministerio de Obras Públicas y Urbanismo; 1988. Spanish.

25. RDL1/2001, Real Decreto Legislativo 1/2001, de 20 de julio, por el que se aprueba el texto refundido de la Ley de Aguas. Madrid (Spain): Ministerio de Medio Ambiente, Official State Bulletin; 2001. Spanish.

26. RD849/1986, Real Decreto 849/1986, de 11 de abril, por el que se aprueba el Reglamento del Dominio Público Hidráulico, que desarrolla los títulos preliminar I, IV, V, VI y VII de la Ley 29/1985, de 2 de agosto, de Aguas. Madrid (Spain): Ministerio de Obras Públicas y Urbanismo; 1986. Spanish.

27. RD638/2016, Real Decreto 638/2016, de 9 de diciembre, por el que se modifica el Reglamento del Dominio Público Hidráulico aprobado por el Real Decreto 849/1986, de 11 de abril, el Reglamento de Planificación Hidrológica, aprobado por el Real Decreto 907/2007, de 6 de julio, y otros reglamentos en materia de gestión de riesgos de inundación, caudales ecológicos, reservas hidrológicas y vertidos de aguas residuales. Madrid (Spain): Ministerio de Agricultura y Pesca, Alimentación y Medio Ambiente; 2016. Spanish.

28. L7/2007, Ley 7/2007, de 9 de julio, de Gestión Integrada de la Calidad Ambiental. Madrid (Spain): Official Bulletin of the Andalusian Autonomous Government; 2007. Spanish.

29. L11/2014, Ley 11/2014, de 4 de diciembre, de Prevención y Protección Ambiental de Aragón. Madrid (Spain): Comunidad Autónoma de Aragón; 2014. Spanish.

30. L17/2006, Ley 17/2006, de 11 de diciembre, de control ambiental integrado. Madrid (Spain): Official State Bulletin; 2006. Spanish.

31. D16/2015, Decreto 16/2015, de 10 de abril, de ordenación sanitaria territorial de la comunidad autónoma de las Illes Balears. Madrid (Spain): Órgano Consejo De Gobierno; 2015. Spanish. 
32. L12/2016, Ley 12/2016, de 17 de agosto, de evaluación ambiental de las Illes Balears. Madrid (Spain): Comunidad Autónoma de las Illes Balears, Official State Bulletin; 2016. Spanish.

33. L3/2008, Ley 3/2008, de 23 de mayo, de ordenación de la minería de Galicia. Madrid (Spain): Órgano Presidencia De La Junta De Galicia; 2008. Spanish.

34. RD1/2016, Real Decreto 1/2016, de 8 de enero, por el que se aprueba la revisión de los Planes Hidrológicos de las demarcaciones hidrográficas del Cantábrico Occidental, Guadalquivir, Ceuta, Melilla, Segura y Júcar, y de la parte española de las demarcaciones hidrográficas del Cantábrico Oriental, Miño-Sil, Duero, Tajo, Guadiana y Ebro. Madrid (Spain): Ministerio de Agricultura, Official State Bulletin; 2016. Spanish.

35. ODZ99, Ordenanza Municipal de Medios de Intervención en la Actividad Urbanística. Zaragoza (Spain): BOPZ; 2011. Spanish.

36. Garrido Schneider E, García-Gil A, Arrazola Martínez C, Escayola Calvo O, Sánchez Navarro JA. Usefulness of a groundwater temperature baseline monitoring network for the identification of thermal interferences between shallow geothermal exploitation systems in urban environments. In: Calvache ML, Duque C, Pulido-Velazquez D, editors. Congress on Groundwater and Global Change in the Western Mediterranean Granada. Reading (UK): International Association of Hydrogeologists; 2017.

37. Guardiola-Albert C, Nuria Naranjo N, De la Losa A, Martínez M, Villarroya F, Barón A. Los pozos abandonados como fuente puntual de contaminación de los acuíferos. Ideas para una normativa de clausura de captaciones en desuso. Madrid (Spain): Congreso Ibérico sobre agua subterránea, medio ambiente, salud y patrimonio; 2018; p. 307-16. Spanish.

38. Attard G, Bayer P, Rossier Y, Blum P, Eisenlohr L. A novel concept for managing thermal interference between geothermal systems in cities. Renew Energy. 2020;145:914-24.

39. Alcaraz M, García-Gil A, Vázquez-Suñé E, Velasco V. Use rights markets for shallow geothermal energy management. Appl Energy. 2016;172:34-46.

40. Feuvre PL, Cox CSJ. Ground Source Heating and Cooling Pumps in England and Wales: State of Play and Future Trends (Environment Agency Report). Bristol (UK): Environment Agency; 2009.

41. AEMET. Resumen anual climatologico 2018. Madrid (Spain): Ministry for the Ecological Transition; 2018. Spanish.

42. Muela Maya S, García-Gil A, Garrido Schneider E, Mejías Moreno M, Epting J, Vázquez-Suñé E, et al. An upscaling procedure for the optimal implementation of open-loop geothermal energy systems into hydrogeological models. J Hydrol. 2018;563:155-66.

43. García-Gil A, Epting J, Garrido E, Vázquez-Suñé E, Lázaro JM, Sánchez Navarro JÁ, et al. A city scale study on the effects of intensive groundwater heat pump systems on heavy metal contents in groundwater. Sci Total Environ. 2016;572:1047-58.

44. García-Gil A, Garrido Schneider E, Mejías M, Barceló D, Vázquez-Suñé E, Díaz-Cruz S. Occurrence of pharmaceuticals and personal care products in 
the urban aquifer of Zaragoza (Spain) and its relationship with intensive shallow geothermal energy exploitation. J Hydrol. 2018;566:629-42.

45. García-Gil A, Gasco-Cavero S, Garrido E, Mejías M, Epting J, Navarro-Elipe M, et al. Decreased waterborne pathogenic bacteria in an urban aquifer related to intense shallow geothermal exploitation. Sci Total Environ. 2018;633:765-75.

46. Brielmann H, Griebler C, Schmidt SI, Michel R, Lueders T. Effects of thermal energy discharge on shallow groundwater ecosystems. FEMS Microbiol Ecol. 2009;68(3):273-86.

How to cite this article:

García Gil A, Mejías Moreno M. Current Legal Framework on Shallow Geothermal Energy Use in Spain. J Sustain Res. 2020;2(1):e200005. https://doi.org/10.20900/jsr20200005 